\author{
January 2018, VOLUME 6, ISSUE 1, 36 - 52 \\ E-ISSN NO: $2289-4489$
}

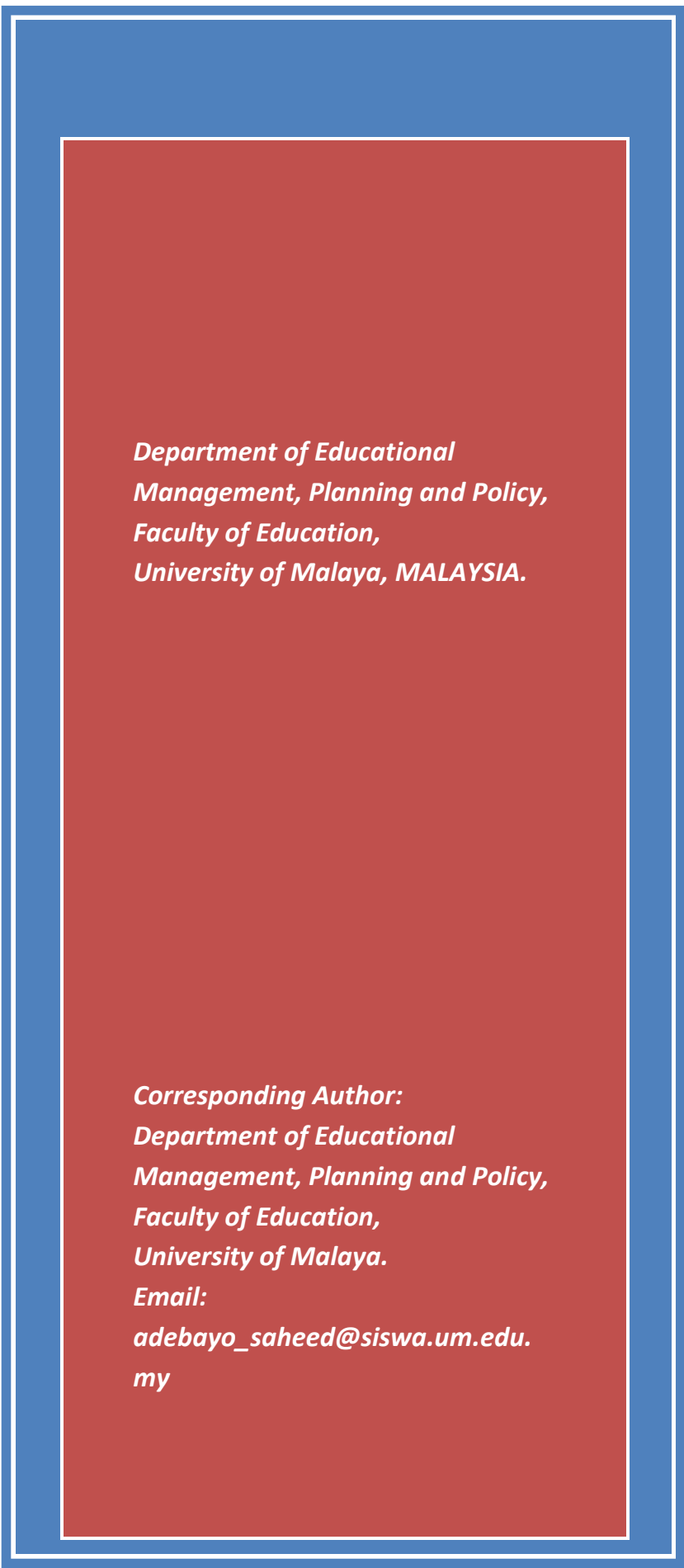

\title{
LEADERSHIP AND STAFF ORGANIZATIONAL CITIZENSHIP BEHAVIOUR IN HIGHER EDUCATION INSTITUTIONS: A QUANTITATIVE ANALYSIS
}

Adebayo Saheed Adewale, Simin Ghavifekr (PhD)\& Megat Ahmad Kamaluddin Megat Daud (PhD)

Department of Educational

Management, Planning and Policy,

Faculty of Education,

University of Malaya, MALAYSIA.

Corresponding Author:

artment of Educational

Management, Planning and Policy,

Faculty of Education,

University of Malaya.

Email:

adebayo_saheed@siswa.um.edu.

my

\section{ABSTRACT}

Higher education institutions are known for producing skilled manpower needed to attain sustainable and holistic development. These institutions cannot achieve their predetermined goals without effective leadership. Leadership is an important factor in an organization. Academic leaders are pivot of change in any higher education institution. As a change agent, the success and failure of the system depend on academic leaders. Their belief and judgment about themselves, attitude towards change and policy tell in every aspect of education system. Therefore, this study examined the impact of leadership self-efficacy and change oriented behaviour on staff organizational citizenship behaviour in higher education institutions. It adopted a quantitative research design. A questionnaire consisting of 40 items was used to gather information from 420 respondents who were randomly selected across 10 different public higher education institutions in Lagos State, Nigeria. Structural Equation Modelling(SEM) was used in analysing the data collected in this study. The findings show that leadership self-efficacy, change oriented behaviour and change policy impact significantly on staff organizational citizenship behaviour. In order to improve staff organizational citizenship behaviour and performance in higher education institutions, academic leaders must display a high self-efficacy, be open to innovation, ensure effective communication and adopt friendly policy that will stimulate staff. If all these are put in place, higher education institutions will be able to achieve their set goals and respond positively to the needs of different stakeholders.

Keywords: Leadership Self-Efficacy, Change Oriented Behaviour, Organizational Citizenship Behaviour, Higher Education Institutions, Academic Leaders. 


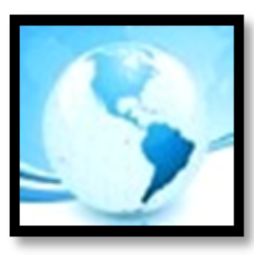

\section{MALAYSIAN ONLINE JOURNAL OF EDUCATIONAL MANAGEMENT (MOJEM)}

\section{INTRODUCTION}

Education has been described as the bedrock of national development. It helps in the development of a culturally and socially tolerant people who are able to exercise ethical and moral considerations in national and local affairs, imbibed with community spirit (Jegede, 2000). Higher education institutions are renowned for producing required manpower needed to attain holistic and sustainable development (Ijaz et al., 2012; McCaffery, 2004). It is also believed that the sector has also frequently help forge national identity by facilitating training and further training of public service employees through seminars, symposia, workshops and other means (Fagbamiye, 2004). This shows that there are numerous tasks ahead of higher education institutions. Idogho (2011) reported in their study that higher education cannot achieve its set goals of establishment and meet up with the global demand if it is not effectively and adequately managed.

Leadership is considered as a factor that has a major influence on the performance of organizations, managers and employees (Sathye, 2004). It is conceived as a set of traits, values, qualities and behaviours displayed by the leader that foster and encourage the participation, commitment and development of followers. Academic leaders are the pivot of change in higher institution of learning. The success or failure of the system depends on them (Shahmandi et al., 2011). The effectiveness of higher education, staff and students depends on the effectiveness of its leaders (Bass \& Riggio, 2005). Academic leaders' work style, level of acceptability and will to change are the most important factors which set the credibility of the higher educational institutions (Harris, 2008). According to Ramsden (1998), effective academic leadership in higher education is a function of several factors or characteristics which include: leadership in teaching, leadership in research, strategic vision and networking, collaborative and motivational leadership, fair and efficient management, development and recognition of performance and interpersonal skills.

The global financial crisis and economic recession have a great impact on the development of education, especially in developing countries (Obasi, 2000). This reflects in the falling standard of education in Nigeria. The effect of this falling standard on higher education is that it leads to poor quality of output, continuous strike action, poor leadership, inability to implement change policies, inconsistent policies (Arong \& Ogbadu,2010), low student attendance at lectures, poor supervision, inability to meet up with the global trend in Information and Communication Technology, corruption in tertiary institutions, falling commitment and dedication of lecturers to work (Chinelo, 2011; Odia \& Omofonmwan, 2007), low students' skill (Duze, 2004; Ogum, 2007), moral decadence in universities, inconsistencies in higher education institutions curriculum, societal degradation and a host of other vices (Akinsanya \& Omotayo, 2013; Anya, 2003). Therefore, this study examines the impact of leadership selfefficacy, change oriented behaviour and change policy on staff organisational citizenship behaviour in Nigerian higher education institutions.

\section{THEORETICAL FOUNDATIONS}

Three different theories guided this research study. These are self-efficacy theory, change leadership theory and organizational citizenship behaviour theory. Each of these is further discussed in the succeeding paragraph:

Self-efficacy theory was propounded by Bandura (1997). He viewed people as self-reflecting, organizing, selfregulating and proactive who are driven by inner impulses. Bandura argued that human functioning is the product of a dynamic interaction of behavioural, personal and environmental influences which he tagged as reciprocal determinism. Interaction results in a Triadic Reciprocity. Individuals will tend to select activities and tasks in which they feel confident and competent while avoiding activities in which they do not excel in. Unless people believe that their actions will have the desired consequences, they have little incentive to engage in those actions (Bandura, 1997). Therefore, the stronger the perceived self-efficacy of an individual, the more active the coping efforts (Van- der- Bijil \& Shortridge-Baggett, 2002). 
Change leadership model developed by Nilakant and Ramanarayan (2006) was also used. This model comprises of four key elements or task including; appreciating change; mobilizing support; executing change; and building change capability. They opined that these complex tasks must be completed effectively in order to achieve the goals of an organization. They presented the tasks in a logical manner with leadership as a core and centre element. They argued that effective change management does not depend on transformational leadership; instead, they proposed four different kinds of leadership attributes that will be needed to accomplish each task. These leadership attributes are: cognitive tuner; people catalyser; system architect and efficacy builder. The strength of this theory lies in its ability to incorporate leadership style which is appropriate at each stage and level of change. This enables leaders to know the type of character that is expected of them in order to effect the real change (Nilakarant \& Ramranarayan, 2006).

The theory of Organizational Citizenship Behaviour was first introduced by Dennis Organ in 1988. Organ (1997) provided an expanded review of Organizational Citizenship Behaviour and defined it as individual behaviour that is discretionary, not directly recognized by the formal reward system and that, which in total, stimulates the effective functioning of the organization. By discretionary, he meant that the behaviour is not an enforceable requirement of the role or the job description, that is, the clearly specifiable terms of the person's employment construct with the organization; the behaviour is rather a matter of personal choice, such that, its omission is not generally understood as punishable. These behaviours are the actions that are not demanded by the formal job responsibilities but contribute to the performance of the organization (Farh et al., 2004). Organ (1997) identified five common behaviours which he used to describe the Organizational Citizenship Behaviour theory including; courtesy, civic virtues, consciousness, altruism and sportsmanship. Based on these theories, the conceptual framework is presented in the diagram below:

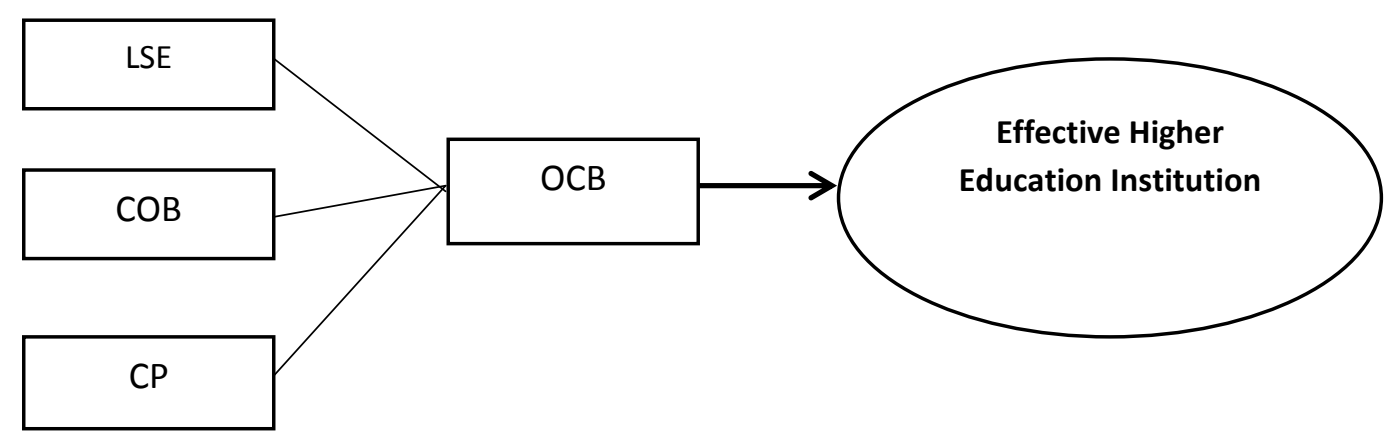

Figure 1: Conceptual Framework of the Study (Source: Bandura, 1997; Nilakarant \&Ramranarayan, 2006; Organ, 1997)

From, the diagram in Figure 1 above, LSE means leadership self-efficacy; COB means change oriented behaviour; CP means change policy while OCB refers to organizational citizenship behaviour. The conceptual framework further shows that academic leader's self-efficacy, change oriented behaviour and change policy affect the organizational citizenship behaviour of staff. The effects of the interaction among these four variables result into effective performance of higher education institutions. Therefore, organizational citizenship behaviour of staff is influenced by leaders' self-efficacy, change oriented behaviour of leaders and change policy. 


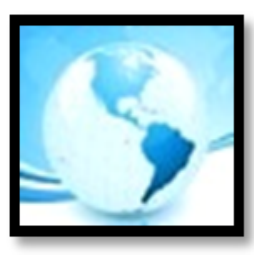

\section{MALAYSIAN ONLINE JOURNAL OF EDUCATIONAL MANAGEMENT (MOJEM)}

Based on these, the following research hypotheses were formulated to guide this study:

$\mathrm{H}_{1}$ : Leadership self-efficacy impact on staff organizational citizenship behaviour in higher education institutions.

$\mathrm{H}_{2}$ : Change oriented behaviour of leaders' impact on staff organizational citizenship behaviour in higher education institutions.

$\mathrm{H}_{3}$ : Change policy impact on staff organizational citizenship behaviour in higher education institutions.

\section{LITERATURE REVIEW}

\section{Leadership Self-efficacy}

Self-efficacy refers to people's judgements about their capability to perform particular tasks. Bandura and Nancy (1977) conceived self-efficacy as the belief in one's capabilities to organize and execute course of action required to manage prospective situations. Lunenburg (2011) conceived self-efficacy as the task-specific version of selfesteem which influences people's ability to learn, motivation and performance. Base on this, people tend to do those tasks which they believe they will be successful at. This is in line with the finding of Van der Bijil and Shortridge-Baggett (2002) when they found that individuals are more likely to engage in activities for which they have high self-efficacy and less likely to engage in those they do not and that one's belief in the likelihood of goal completion can be motivating in itself.

Leadership self-efficacy can be described as the belief and judgement about their capability and ability to accomplish tasks. Based on this, Bandura (1997) divided people into two categories in relation to their self-efficacy. These are high self-efficacy and low self-efficacy. Leaders with high self-efficacy show are goal-oriented, dedicated, committed to work and mobilise all their resources towards achieving organizational goals (Bandura, 2004). In addition, they provide support for their subordinate, communicate and change ideas in a pleasant manner that will stimulate their followers towards imbibing the change (Lunenburg, 2011). These leaders do not complain about difficult task, rather they find a way out (Bandura, 1997). These account for their high success performance in their organization (Yukl, 2010). On the other hand, leaders with low self-efficacy complain about task, show lazy attitude towards difficulty task, feel reluctant to take challenge and fall to motivate staff towards task (Bandura \& Locke, 2003; Bandura, 1997). Leadership self-efficacy is influenced by four factors including; past performance, verbal persuasion, experience and emotional cues (Bandura, 1997).

\section{Change-Oriented Behaviour}

The term change has a lot of meanings. It implies different meanings to different people (Owen, 2011; Yukl, 2010). Therefore, some researchers and scholars came up with various definition of the concept. Dawson and Andriopoulos (2014) conceived change as something which comes with a new thing that redefines, refines, replaces what has gone before or previous practices. Haripogal (2006) defined change as the need to make or become different, give or begin to have different form. It means dissatisfaction with the old and the belief in the new (Yukl, 2010).

Leadership is an important concept in effecting change in an organization. It focuses on behaviour, performance, value and progress of an organization (Owen \& Valesky, 2011; Yukl,2010; Bush, 2008). It helps in achieving organizational goals by influencing, persuading and encouraging the task force within the organization (Patridge, 2007). In the academic set up, leaders need to uphold, develop and enhance their core competencies in order to effect a change in higher learning institutions (McCaffery, 2004; Ramsden, 1998). 


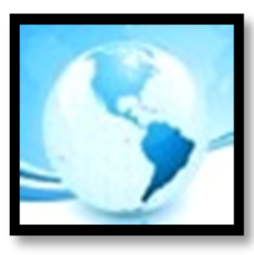

\section{MALAYSIAN ONLINE JOURNAL OF EDUCATIONAL MANAGEMENT (MOJEM)}

For this reason, Jackson (2000) stressed that for effective leadership, leaders must possess the right skills and competencies while striking a balance between their four capabilities which are: understanding customers, engaging people, operational excellence, leadership vision and values. Therefore, Yukl (2010) proposed the threedimensional leadership behaviour model which he tagged as taxonomy of leaders' behaviour. These include; task behaviour, relation behaviour and change behaviour. Change behaviour involves monitoring of external environment, proposing an innovative strategy or new vision for the organization; encouraging innovative thinking among staff in an organization and taking risk to promote necessary change. Therefore, Kotter (1996) proposed eight stages of creating major change in an organization including;

\section{Leadership Self-Efficacy, Change Oriented Behaviour \& Change Policy on Staff OCB}

Leadership play a vital role in an organization as it determines and influences the outcome and performance of both employees and the organization itself (Wang et al., 2005). Their belief, attitude and style have a great influence on the existence of the organization. Based on this, different past studies confirmed that a strong and positive relationship exists between the attitude, behaviour and style of leaders and the performance of their subordinates (Locke \&Latham, 2002; Bandura, 2004; Lunenburg, 2011). Irrespective of the type of the organization involved, the leader's behaviour usually determine the success and otherwise of an organization (Owens \& Valesky, 2011). Similarly, Vigoda-Gadat (2007) found that a strong and positive relationship exists between leadership style and performance of staff in an organization most especially in relation to the Organizational citizenship behaviour of workers. Furthermore, Lunenburg (2011) discovered from his findings that self-efficacy has a direct effect on worker's level of commitment and level of persistence when dealing with or faced with a complex situation.

Bandura (1997) opined in his theory of self-efficacy that leadership self-efficacy influences the goals which the staff choose for themselves; the level of commitment displayed by workers to work; attitude towards learning and dealing with complex tasks. If leaders show a positive attitude to difficult tasks, it will transit to their followers. They will also display such attitude to work and will strive not to give, but if the leader displays a low self-efficacy, the subordinate will tend to turn a lukewarm attitude to the task. Based on this, Bandura and Locke (2003) summarized the impact of leadership self-efficacy as the most important determinant factor which influences performance of workers and influences their organizational citizenship behaviour.

Change is a vital tool for attaining organizational goals. Leader's behaviour about change will go a long way to influence followers in achieving organizational goals (Kinicki and Fugate, 2013; Owen and Valesky, 2011). Leaders need to ensure effective communication of change idea, plan and policy as a way of soliciting subordinate support in an organization. Effective communication is an essential ingredient in effecting change plans in an organization. (Kinicki \& Fugate, 2013; Yukl, 2010).

Organizational policy has a great impact on members of staff in an organization. Its effect on organization cannot be over emphasized. Starr (2011) argued that political intervention in educational policies has contributed in staff resistance to change which later affect attainment of goals of school administrators. This is also the case in Nigeria higher learning institutions where the politicians decide what will happen in the academic community. Based on this, Espinosa (2010) advised that the politicization of education at all levels must be controlled and universities should be given autonomy in order to meet up with the trend in the changing global community. Once an organizational policy takes care of human nature and is designed in-line with staff needs, there will be commitment from staff which will increase their self-efficacy and attitude towards work. 


\section{METHODOLOGY}

\section{Research Design}

Research design shows a systemic plan of how a research study will be done (Berg \& Lune, 2014). This study adopted a quantitative descriptive research design. The quantitative research design enables researcher to determine interaction among different variables (Trochim et al., 2016; Meyers, 2013). Therefore, the quantitative research design will enable the researchers to determine the kind of interaction that exist among leadership selfefficacy, change oriented behaviour and organizational citizenship behaviour.

\section{Population and Sampling}

The population of this study consists of the teaching, administrative and support staff in 10 public higher education institutions in Lagos State, Nigeria. The population in this study consists of about 40,000 staff. Out of this, we decided to use a total of 420 respondents based on recommendation of Krejcie and Morgan. Krejcie and Morgan (1970) sample table suggested that 380 respondents are appropriate for this number. Therefore, the researchers increased the sample to 420 in order to avoid any doubt and therefore ensure a robust outcome. Furthermore, random sampling technique was adopted in selecting respondents for this study. Through the random sampling technique, every member of the population has equal right and chance of being selected (Trochim et al., 2016; Creswell, 2012). With this, all cadre or category of staff in higher education institutions is represented in this study.

\section{Research Instrument}

The research instrument for this study consisted of adopted and adapted questionnaire from previous studies by Bandura (1997) on Self-Efficacy; Osipova and Ayupora (2013) on Change Management; Jutila (2007) on Organizational Change; Tang et al. (2011) on Organizational Policies and Bukhari (2008) on Organizational Citizenship Behaviour. It has 40 items consist of 5 sections (A, B, C, D \& E). Section A of the questionnaire centres on demographic information of the respondents. Section B with 10 items centres on leadership self-efficacy. In addition, Section $C$ with 9 items centres on change-oriented behaviour of academic leaders. Moreover, Section D consists of 11 items that centre on change policy while Section E with 10 questions centres on organizational citizenship behaviour respectively. This questionnaire was tested before it was finally distributed to the respondents. This questionnaire was designed on 6 Likert scale of Entirely Disagree (ED), Mostly Disagree (MD), Disagree (D), Agree (A), Mostly Agree (MA) and Entirely Agree (EA) respectively.

\section{Reliability and Validity}

Reliability test helps us to measure the repeatability and consistency of an outcome (Mayer, 2013). It tells us how much we can depend on the outcome (Pallant, 2011). Therefore, the researchers examined the reliability of all the 40 items in the questionnaire used in this study using Cronbach's Alpha. The result is presented in Table 1 below:

Table 1

Reliability Statistics for Each of the Variables

\begin{tabular}{lccc}
\hline Variable & N & \multicolumn{2}{l}{ Cronbach's Alpha } \\
\hline Leadership Self-Efficacy & 10 & .945 & All items are accepted/reliable \\
Change Oriented Behaviour & 9 & .947 & All items are accepted/reliable \\
Change Policy & 11 & .960 & All items are accepted/reliable \\
Organizational Citizenship Behaviour 10 & .915 & All items are accepted/reliable \\
\hline
\end{tabular}




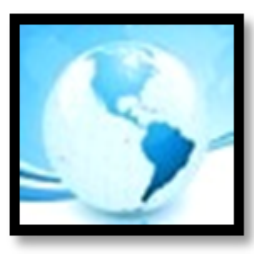

\section{MALAYSIAN ONLINE JOURNAL OF EDUCATIONAL MANAGEMENT (MOJEM)}

Table 1 above shows that there are 10 items under leadership self-efficacy. The value of the Cronbach's Alpha for these 10 items under Leadership Self-Efficacy is .945. It further reveals that there are 9 items under Change Oriented Behaviour with a Cronbach's Alpha of .947. In addition, Change Policy has 11 items with a Cronbach's Alpha of .960 while Organizational Citizenship Behaviour has 10 items with a Cronbach Alpha of .915. According to Pallant (2011), values above .7 are considered acceptable and values above .8 are preferable. Therefore, the value of the Cronbach's Alpha for all the items in each variable shows very good internal consistency reliability for this scale and all the 40 items in the questionnaire are found to be reliable.

In addition, the questionnaire was validated by four different experts in the field of educational leadership, management and organizational behaviour including 1 professor, 1 associate professor and 2 senior lecturers. Each expert gave his or her opinion and suggestion for the questionnaire's improvement. Later, the questionnaire was corrected according to the expert's opinion. With the expert's opinion and result of the test, validity of the instrument is guaranteed. Expert's opinion was judged as a vital way of validating a research instrument (Fraenkel et al., 2015; Mayers, 2013; Creswell, 2012). Therefore, the result of the validity test for this study is presented as below:

The 40 items in the leadership self-efficacy, change-oriented behaviour and organizational citizenship behaviour were subjected to principal components analysis (PCA) using Statistical Package for Social Sciences (SPSS) version 21. Prior to this, the suitability of data for factor analysis was assessed. A careful inspection of the correlation matrix shows the presence of many coefficients of .3 and above. The Kaiser-Mayer-Olkin value was .972 which exceeds the recommended value of .6 suggested by Kaiser (1970). The Bartlett's Test of Sphericity reached statistically significant of .000 . These support the factorability of the correlation matrix. The principal component analysis shows the presence of four components with eigenvalue greater than 1, explaining $43.8 \%, 9.7 \%, 4.0 \%$ and $3.6 \%$ of the variance respectively. A critical inspection of the scree plot graph shows a clear break after the fourth component. Going by the Catell's (1966) The Scree Test, it decided to retain four components for further investigation. The four components solution explained a total of $65.5 \%$ of the variance with component 1 contributing $43.8 \%$, component 2 contributed $9.7 \%$, component 3 contributed $6.4 \%$ and component 4 contributed $5.6 \%$ respectively.

\section{Administration of the Instrument and Collection of Data}

The questionnaire was distributed to over 700 respondents composed of selected teaching, administrative and technical staff across 10 different higher education institutions in Lagos State, Nigeria. These respondents were contacted in their various offices prior to the distribution of the questionnaire. The researchers solicited their support to participate in the study. Hence, none of the respondent is fake or compelled to take part in this study. Thereafter, respondents were contacted in their various offices and institutions. Effort was made to discuss the rationale of the study to them. The researchers also made effort to explain some key terms for better understanding. Respondents were given two weeks to read through the questionnaire and fill them in accordingly. After two weeks, the researchers went back to these institutions to collect the questionnaire in person from these respondents. At the end, a total of 420 questionnaires were returned and filled correctly. Therefore, the returned number meet the suggestion of Krejcie and Morgan (1970) with a number of 420 respondents sampled in this study.

\section{Data Analysis}

After collecting the data, information was then keyed-in the SPSS and analysed using descriptive statistics like simple percentage for the demographic information and inferential statistics such as factor analysis and structural equation modelling for the hypotheses. The structural equation modelling is a statistical model which explains the inter-relationship among multiple variables and enables researchers to represent theoretical concepts using 


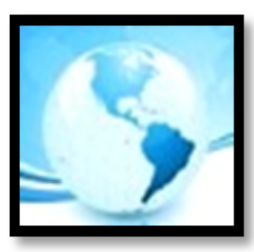

various measures which will reduce the measurement error and provides better understanding of the phenomenon been discussed (Hair et al.,2010).

\section{FINDINGS}

This section presents a detailed result of the analysis made from the data collected in this study. It started with an analysis of the demographic information of respondents using descriptive statistics and a detailed analysis of the hypotheses using structural equation modelling. Detailed result is presented in the sub-headings below:

Table 2

Demographic Information of Respondents

\begin{tabular}{llcc}
\hline \multicolumn{1}{c}{ Items } & & $\mathbf{N}$ & \% \\
\hline \multirow{2}{*}{ Gender: } & Female & 288 & 68.6 \\
& Male & 132 & 31.4 \\
Qualification: & Bachelor & 78 & 18.6 \\
& Master & 224 & 53.3 \\
& PhD & 118 & 28.1 \\
Institution: & College of Education & 137 & 32.6 \\
& Polytechnics & 133 & 31.7 \\
& University & 150 & 35.7 \\
& & & \\
Staff Type: & Academic & 303 & 72.1 \\
& Non-Academic & 117 & 27.9 \\
& & & 100 \\
\hline
\end{tabular}

Table 2 above presents the demographic information of respondents that took part in this study. From the table, $288(68.6 \%)$ of the respondents and $132(31.4 \%)$ are male. On the highest academic qualification of respondents, $78(18.6 \%)$ out of the 420 respondents have Bachelor degree. 224 (53.3\%) have Master degree and 118(28.1\%) have Doctor of Philosophy as their highest academic qualification. The table further shows that 137 (32.6\%) of these respondents worked in Colleges of Education, 133 (31.7\%) worked in Polytechnics and 150(35.7\%) worked in universities. Finally, 303 (72.1\%) of the respondents are members of academic staff while $117(27.9 \%)$ respondents are non-academic staff in higher education institutions.

\section{Confirmatory Factor Analysis and Structural Equation Modelling}

The confirmatory factor analysis section shows the result of the model fit, correlation of latent construct and regression weight. These are preliminary tests that must be run before the structural equation modelling. Detailed result of the confirmatory analysis and structural equation modelling are presented below: 


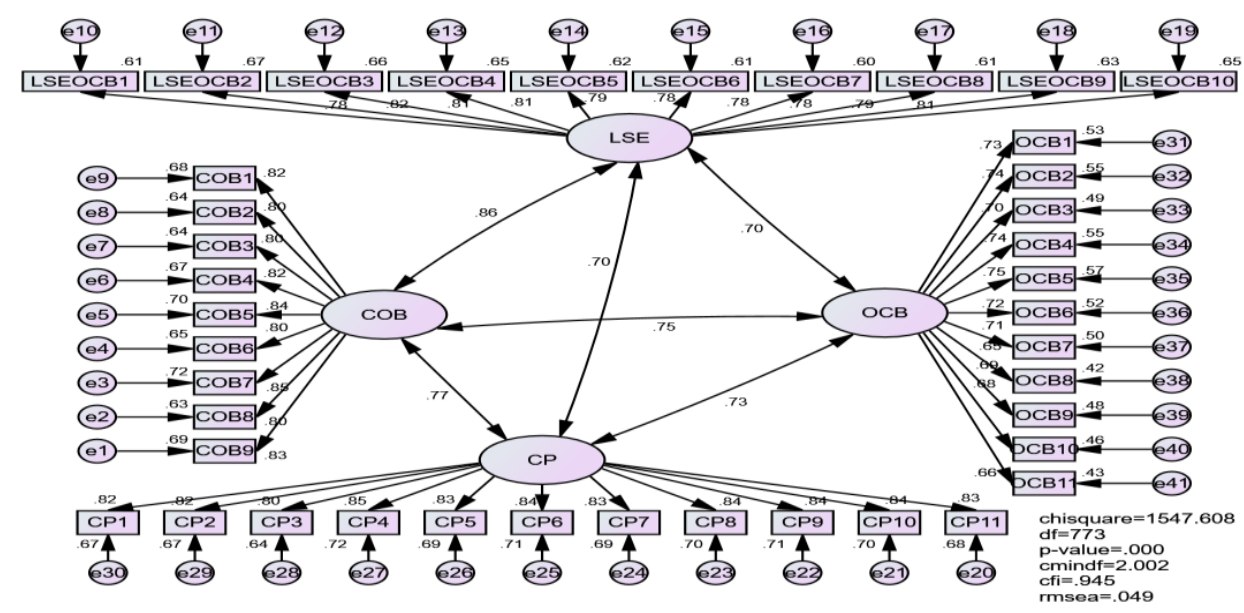

Figure 2: Model Fit

At a close look at the $p$-value in the diagram in Figure 2 above, the researcher observed that the value of the $p$ value is $.000(.000>.05)$. This is statistically significant and conforms with the suggestion Awang (2014). Similarly, the result of the RMSEA in the model above is .049. This is less than 0.08 suggested by Awang (2014). It therefore implies that the model passed and meets up with the requirement of absolute fit. Next, the researchers went further to check for the CFI result.

Considering the value of CFI in the diagram, it was found that the value is .945 which can be approximated to .95. From the suggestion of Awang (2014), it is clear that this model passed the incremental fit as the value falls within the acceptable region. Also, the value of the chi-square of the model is 1547.608 . This shows that it is above the suggested value for the parsimonious fit. Finally, the diagram above shows that all the items are above .70 which shows that the convergent validity of the model has been achieved.

Table 3

Overall Fit Index

\begin{tabular}{lll}
\hline Fit Indexes & Value & Remark \\
\hline Chi-Square & 1547.608 & Acceptable \\
CFI & .945 & Acceptable \\
RMSEA & .049 & Acceptable \\
DF & 773 & Acceptable \\
\hline
\end{tabular}

The overall model fit in Table 3 above indicated that the minimum level was achieved. The four-factor structure model chi-square yielded a relatively satisfactory value of 1547.608 with a degree of freedom of 773 . The value of the RMSEA is 0.5 while the value of the CFI is .945 . The relative chi-square (CMIN/df) was estimated to be 2.002 which is below the threshold point of 3.0 and 5.0 suggested by Kline (2005); Hair et al. (2010) and Awang (2014) respectively. In addition, the direction of the magnitude of the loadings was statistically significant. This therefore implies that the model is free from offending the estimates and meets the requirement for internal consistency. 


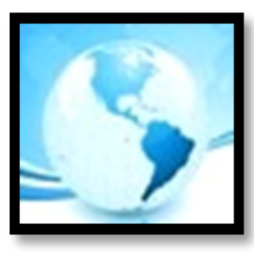

We can conclude that the model is fit. After attaining significance level, the researcher went further to check for the correlation of the variables in this model. The result derived is presented in Table 4 below:

Table 4

Correlation of Latent Construct

\begin{tabular}{ll} 
Ttems & Estlmate \\
\hline COB $\longleftrightarrow$ LSE & .859 \\
COB $\longleftrightarrow$ CP & .769 \\
CP $\longleftrightarrow$ OCB & .731 \\
LSE $\longleftrightarrow$ OCB & .697 \\
COB $\longleftrightarrow$ OCB & .750 \\
LSE $\longleftrightarrow$ CP & .699 \\
\hline
\end{tabular}

The correlation table in Table 4 above shows the relationship between latent construct in the model. It was found that the correlation between change-oriented behaviour (COB) and leadership self-efficacy is .859. The correlation between change-oriented behaviour $(\mathrm{COB})$ and change policy $(\mathrm{CP})$ is .769. In addition, the value of the correlation between change policy (CP) and organizational citizenship behaviour (OCB) is .731. Also, it was found that the correlation between leadership self-efficacy and organizational citizenship behaviour is .697. Furthermore, the table reveals that the correlation between change-oriented behaviour (COB) and organizational citizenship behaviour (OCB) is .750, Finally, the correlation between leadership self-efficacy (LSE) and change policy (CP) is .699. A careful observation of the result of the correlation table shows that the value of the correlation is above .65. This shows that the correlation is suitable and acceptable. The next step is to check for the Structural Equation Modelling. The result is presented below:

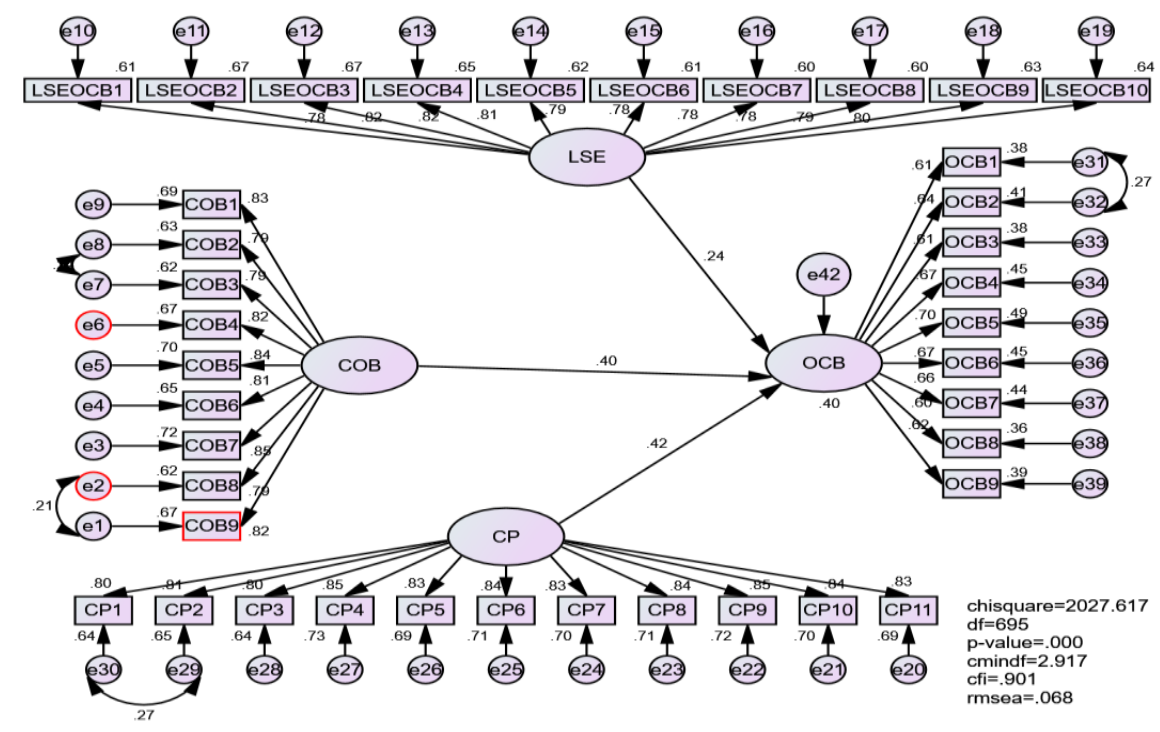

Figure 3: The Standardized Regression Weight 


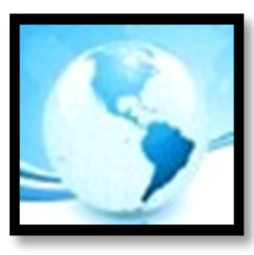

\section{MALAYSIAN ONLINE JOURNAL OF EDUCATIONAL MANAGEMENT (MOJEM)}

From the diagram in Figure 3 above, the standardized beta estimate for the effect of leadership self-efficacy on staff organizational citizenship behaviour is 0.24 . In addition, the standardized estimate of change-oriented behaviour of leaders has 0.40 effects on staff organizational citizenship behaviour while the change policy has 0.42 effects on staff organizational citizenship behaviour. The value of coefficient of determination $R^{2}$ is 0.40 . This implies that these three exogenous constructs (leadership self-efficacy, change-oriented behaviour and change policy) have contributed $40 \%$ to the change in staff organizational citizenship behaviour in higher education institutions in Lagos State. It was also found from model diagram above that change policy contributed most to the staff organizational citizenship behaviour with 0.40 . This is followed by change-oriented behaviour of leaders with 0.40 while leadership self-efficacy was at the last with 0.24 . The four factors in structure model chi-square yielded a relatively satisfactory value of 2027.617 with degree of freedom of 695 . The value of the RMSEA is 0.068 while the value of the CFI is .901 . The relative chi-square (CMIN/df) was estimated to be 2.917 which is below the threshold point of 3.0 and 5.0 suggested by (Kline, 2005; Hair et al., 2010) and Awang (2014) respectively.

\section{Analysis of Covariance}

This section presents the result obtained on analysis of the covariance shown in the standardized regression weight table above. The covariance table shows the result of estimate, standard error, critical value and $p$-value of the covariance as contain in Table 5 below.

Table 5

Covariance Table

\begin{tabular}{lcccc}
\hline Items & Estimate & Standard Error & Critical Ratio & P-Value \\
\hline $\mathrm{e} 31 \longrightarrow \mathrm{e} 2$ & .170 & .036 & 4.772 & .000 \\
$\mathrm{e} 1 \longrightarrow \mathrm{e} 2$ & .180 & .029 & 3.701 & .000 \\
$\mathrm{e} 7 \longleftrightarrow \mathrm{e}$ & .103 & .024 & 4.228 & .000 \\
$\mathrm{e} 29 \longleftrightarrow \mathrm{e} 90$ & .125 & .026 & 4.781 & .000 \\
\hline
\end{tabular}

In Table 5 above, it was found that e31 to e32 has .170, .036, 4.772 and .000 for estimate, standard error, critical ratio and p-value respectively. Asl0, e1 to e2 shows estimate of .180, standard error of .029, critical ratio of 3.701 and was found significant at $p=.000$. Furthermore, e7 to e8 shows estimate of .103 , standard error of .024 with critical ratio of 4.228 and p-value of .000. Finally, e29 to e30 shows estimate of .125, standard error of .026, critical ratio of 4.781 and $p$-value of .000 . The implication of these results is that all the items in covariance are statistically significant based on the result of their $p$-values.

\section{Result of Hypothesis Testing for the Respected Path}

This section presents the final result of each of the hypothesis based on the findings derived from the structural equation modelling analysis. Effort was made to answer each of the three hypotheses set to determine whether they are significant or not. Detailed result is presented in Table 6 below: 


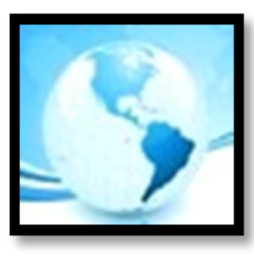

MALAYSIAN ONLINE JOURNAL OF

EDUCATIONAL MANAGEMENT

(MOJEM)

Table 6

Hypothesis Testing

\begin{tabular}{lll}
\hline Hypothesis Statement & Estimate P-Value Result \\
\hline
\end{tabular}

$\mathrm{H}_{1}$ : Leadership self-efficacy has significant

impact on staff organizational citizenship

behaviour.

$.172 \quad .000 \quad$ Supported

$\mathrm{H}_{2}$ : Change-oriented behaviour has significant

impact on staff organizational citizenship

behaviour

$.273 \quad .000 \quad$ Supported

$\mathrm{H}_{3}$ : Change policy has significant impact on

staff organizational citizenship behaviour

$.272 \quad .000 \quad$ Supported

Analysis in Table 6 above shows that the structural equation model supported all three hypotheses. The estimated value of the first hypothesis is .172 and it is significant with $p=.000$. This result shows that there is a significant relationship between leadership self-efficacy and staff organizational citizenship behaviour in higher education institutions. It therefore implies that self-efficacy of leaders has something to do with the willingness of the staff to give their upmost best to their organization. In addition, the second hypothesis shows an estimate value of .273 with $p$-value of .000 . This reveals that there is a significant relationship between change-oriented behaviour of leaders and staff organizational citizenship behaviour in higher education institutions. The attitude of leaders towards change and innovations reflect in the staff's display of organizational citizenship behaviour. Finally, the third hypothesis shows an estimate of .272 with $p$-value of .000 . This result shows that there is a statistically significant relationship between change policy introduced and implemented by higher education institutions and the organizational citizenship behaviour of members of staff. This implies that the researchers will accept all the alternative hypotheses in hypotheses 1, 2 and 3 and that the researcher will fail to accept all the null hypotheses. Therefore, the study concludes that leadership self-efficacy, change oriented behaviour and change policy give an impact on staff organizational citizenship behaviour in higher education institutions.

\section{DISCUSSION}

From the first research hypothesis, it was found that leadership self-efficacy has significant impact on staff organizational citizenship behaviour. This implies that whenever academic leaders develop and display high selfefficacy in discharging their duties, there is tendency that their subordinate or followers will develop organizational citizenship behaviour. This shows that leadership is a vital factor in the development of the organization. As reported by Wang et al (2005), leadership determines the outcome and performance of staff and organization. Also, the finding is in line with the position of Vigoda-Gadat (2007) who found from their studies that the performance of staff will be influenced by the efficacy of the leaders who is leading them. In addition, the result also corresponds with the position of Bandura (1997) in his theory of self-efficacy, when he proposed that the selfefficacy of a leader will influence goals which staffs choose for themselves, their level of commitment to work, attitude towards learning and dealing with complex task. Whenever a leader shows positive attitude towards any given task, such positive attitude will reflect on the subordinates which will later lead to organizational citizenship behaviour (Bandura \& Locke, 2003). 


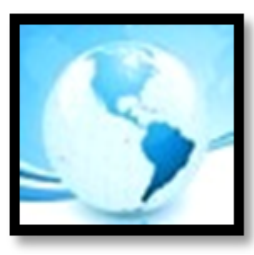

\section{MALAYSIAN ONLINE JOURNAL OF EDUCATIONAL MANAGEMENT (MOJEM)}

In addition, change-oriented behaviour of leaders has a great influence on the organizational citizenship behaviour of staffs in higher education institutions. As found in the analysis, change oriented behaviour has contributed .40 $(40 \%)$ to the change in staff organizational citizenship behaviour in higher education institutions in Lagos State. This contribution was made with an estimate value of .273 and p-value of .000 . This therefore implies that when academic leaders are committed to the change plans, use the right channel of creating their change plans, subordinates will then willingly follow the path of change. This is in line with views of Kotter (1996) when he proposed the eight stages of creating major change in an organization. In addition, effective leadership and ability to communicate the change idea across the subordinate is vital. This is in consonance with views of Kinicki and Fugate (2013); and Yukl (2010) who found that effective communication is an essential ingredient in effecting change plans in an organization.

Furthermore, organizational policy has impact on staff organizational citizenship behaviour. It is important to note at this junction that educational policies are formulated by government and politicians. Staffs are bound to abide by whatever policy is given to them by the state. In academic institutions, government formulates policies on higher education through the Ministry of Education and the Senate or Governing Council in each institution. Whatever the government representative in each institution says must stand. Therefore, the type of policy formulated by the governing council of these institutions would impact the staff organizational citizenship behaviour. As found in the result of the structural equation modelling, change policy accounts for .42(42\%) of the change in organizational citizenship behaviour of staffs. In addition, the finding is in line with the view of Starr (2011) who opined that political intervention in educational policies impact greatly on staff. This was also supported by Espinoza (2010) who found that educational policies impact greatly on the entire educational system in which staff is inclusive. Therefore, policies of the educational institutions have a long effect on job satisfaction, commitment and organizational citizenship behaviour of staff.

\section{IMPLICATIONS}

Leadership is an important factor in determining the success or failure of higher education institutions. Leaders' belief in their ability to accomplish any task has direct and significant influence on staff's ability to go the extra mile in their work or do more than their primary duties. This shows that the leadership is a key factor in the educational setting. Whenever academic leaders put up a strong and high self-efficacy, their followers will be able to comply and increase their organizational citizenship behaviour but if it's the otherwise, staffs will showcase a nonchalant attitude to work. This will hinder accomplishment of given tasks and attainment of organizational goals. Therefore, academic leaders need to improve and develop their self-efficacy as a way of enhancing the organizational citizenship behaviour of their staff.

Secondly, the world is changing. Therefore, higher education institutions need to dance to the tune of change in the global community. Academic leaders need to imbibe change that will improve the entire education system and stimulate the interest of staff and students. They must show positive attitude towards change and meaningful development irrespective of who brought the idea. As found in the study, change oriented behaviour of academic leaders impact the staff's organizational citizenship behaviour. Thirdly, educational policies introduced and implemented by academic leaders in higher education institutions greatly impacts the organizational citizenship behaviour of staff in these higher education institutions. Therefore, policies must be friendly, inviting and elevating to both staff and students in order to achieve goals set for higher education.

Finally, improving organizational citizenship behaviour of staff revolves around the leader. Their role, attitude, behaviour and administrative policy can make or mar the development of the higher education institution. Therefore, caution must be made in selecting and appointing leaders in various higher education institutions. 


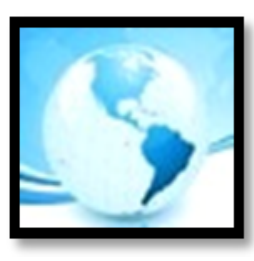

\section{MALAYSIAN ONLINE JOURNAL OF EDUCATIONAL MANAGEMENT (MOJEM)}

\section{CONCLUSION}

In order to increase the organizational citizenship behaviour of staff in higher education institutions and improve commitment of staff, concise effort must be put in place by academic leaders and government representative in each higher education institutions. Academic leaders must ensure that they develop a high self-efficacy and serve as a role-model to their subordinate. In addition, leaders in higher education institutions must be current with the changes in the global community, open to innovation and adopt friendly policies that will enhance the development of staff, students and attainment of higher education goals. If all these measures are put in place by academic leaders, higher education institutions will achieve the targeted goals and thus respond positively to numerous needs of their stakeholders. Not only that, staff and students will then see these institutions as theirs and will be ready to give their best to their institutions at any time.

\section{REREFENCE}

Akinsanya, O.A. \& Omotayo, R.F. (2013). Falling standard of engineering education in Nigeria: Causes and suggestions. International Journal of Advancements in Research and Technology, 2(10), 93 -96.

Anya, O.A. (2003). Leadership education and the development in the $21^{\text {st }}$ century. Vanguard newspaper: October 21, 26.

Arong, F.E. \& Ogbadu, M.A. (2010). Major causes of declining quality of education in Nigeria from administrative perspective: A case study of Dekina Local Government Area. Canadian Social Science, 6(3), 183 -198.

Awang, Z, (2014). A handbook on structural equation modelling for academicians and practitioners; The step by step practical guides for beginners. Malaysia; MPWS Rich Resources.

Bandura, A. (2004). Cultivate self-efficacy for personal and organizational effectiveness. In Locke, E.A(Ed), Handbook of principles of organizational behaviour. Malden, M.A: Blackwell.

Bandura, A \& Locke, E. A. (2003). Negative self-efficacy and goal effects revisited. Journal of Applied Psychology, 88 (1), 87-99.

Bandura, A. (1997). Self-efficacy: The exercise of control. New York: W. H. Freeman.

Bandura, A \& Nancy, E.A. (1977). Analysis of self-efficacy theory of behavioural change. Cognitive Therapy Research, 1 (4), $287-310$.

Bass, B.M., \& Riggio, R.E. (2005). Transformational leadership ( $8^{\text {th }}$ ed.). USA: Taylor and Francis.

Berg, B.L. \& Lune, H. (2014). Qualitative research methods for Social Sciences ( $8^{\text {th }}$ ed.) England: Pearson Education Limited.

Bukhari, Z.U. (2008). Key antecedents of organizational citizenship behaviour in banking sector of Pakistan. International Journal of Business and Management, 3(12), 106 -115.

Bush, T. (2008). Theories of educational leadership and management. (4 ${ }^{\text {th }}$ ed.) London: Sage Publications.

Chinelo, O.D. (2011). Falling standard in Nigeria education: Traceable to proper skills acquisition in schools. Journal of Education Research, 2(1), 803 -808. 


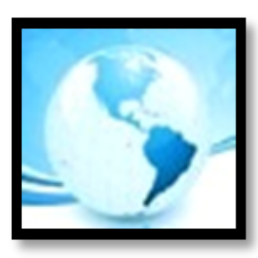

\section{MALAYSIAN ONLINE JOURNAL OF EDUCATIONAL MANAGEMENT (MOJEM)}

Creswell, J.W. (2012). Educational research: Planning, conduction and evaluating quantitative and qualitative research ( $4^{\text {th }}$ ed.) Boston: Pearson.

Dawson, P. \& Andriopoulos, C. (2014). Managing change, creativity and innovation. Los Angeles: Sage Publication.

Duze, C.O. (2004). An evaluation of adequacy of science knowledge acquired by pupils in public and private schools In Delta State. Journal of Educational Research, 30(1), 25 -30.

Espinoza, O. (2010). Alternative approaches on society, state, educational reform and educational policy. In Zajda, J \& Geo-Jaya, M.A (Eds) The politics of education reforms. London: Springer.

Fagbamiye, E.O. (2004). Strategies for addressing the challenges of cross-border provision of higher education, with or without WTO/GATS Regime. A lead paper delivered at the African University Day Celebration at the University of Lagos on November 12, 2004.

Farh, J.L., Zhong, C.B., \& Organ, D.W. (2004). Organizational Citizenship Behavior in the People's Republic of China. Organization Science, 15 (2), 241-253.

Fraenkel, J.R., Wallen, N.E., \& Hyun, H.H. (2015). How to design and evaluate research in education. (9 ${ }^{\text {th }}$ Ed.). New York: McGraw Hill Education.

Hair, J.F., Black, W.C., Babin, B.J., Anderson, R.E., \& Tatham, R.I. (2010). Multivariate data analysis (7 ${ }^{\text {th }}$ ed.). Upper Saddle River, NJ: Pearson Education.

Harigopal, K. (2006). Management of organizational change: Leveraging transformation. (2nd ed.). New Delhi: Response Books.

Harris, A. (2008). Leading sustainable schools. London: Specialist Schools and Academic Trust.

Idogho, P.O. (2011). Higher education in Nigeria and the challenges ahead. European Journal of Educational Studies, 3(2), $269-276$.

ljaz, M., Shahinshah, B.K., Khan, R., Shaheen, A.T. (2012). Role of academic leadership in change management for quality in higher education in Pakistan. Journal of Education and Practice, 3(16),194 - 198.

Jackson, D. (2000). Becoming dynamic: Creating and sustaining the dynamic organization. Hampshire: Macmillan Press Limited.

Jegede, O. (2000). Evolving a national policy on distance education: An agenda for implementation. Education Today, 8 (3), 14-29.

Jutila, H. (2007). A critical appraisal of current change management practices in the business environment of the early 21st century: Organizational change and how it was perceived in Hameelinna Regional Environmental Authority. Finland: Hameelinna Regional Environmental Authority.

Kinicki, A. \& Fugate, M. (2013). Organizational behaviour: Key concepts, skills and best practices. (5th ed.). New York: McGraw-Hill/Irwin.

Kline, R.B. (2005). Principles and practice of structural equation modelling ( $2^{\text {nd }}$ ed.). New York: Guilford Press.

Kotter, J.P. (1996). Leading change. Boston, MA: Harvard Business School Press. 


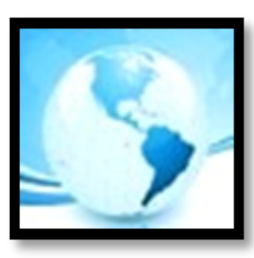

\section{MALAYSIAN ONLINE JOURNAL OF EDUCATIONAL MANAGEMENT (MOJEM)}

Krejcie, R.V., \& Morgan, D.W. (1970). Determining sample size for research activities. Educational and Psychological Measurement, 30(3), $607-610$.

Lunenburg, F. (2011). Self-efficacy in the workplace: Implications for motivation and performance. International Journal of Management, Business and Administration, 14(1), 1-6.

Mayers, A. (2013). Introduction to statistics and SPSS in psychology (1 ${ }^{\text {st }}$ ed.) England: Pearson Education Limited.

McCaffery, P. (2004). The higher education manager's handbook: Effective leadership management in universities and colleges. New York: Routledge Falmer.

Nilakant, V., \& Ramnarayan, S. (2006). Change management: Altering mindsets in a global context. New Delhi: Response Books.

Obasi, E. (2000). The impact of economic recession on universal primary education in Nigeria. International Journal of Educational Development, 20(3), 189 - 207.

Odia, L.O. \& Omofonmwan, S.I. (2007). Educational system in Nigeria: Problems and prospects. Journal of Social Science, 14(1), 81-86.

Ogum, D.N. (2007). On the declining literacy among trainee teachers in Nigeria. African Journal of Educational Development Studies, 4(1), 143-149.

Organ, D.W. (1997). Organizational Citizenship Behaviour: Its construct clean-up time. Human Performance, 10(2), 85-97.

Osipova, A., \& Ayupova, G. (2013). Change management in project work: Survey result. United Kingdom: Deloitte.

Owens, R.G \& Valesky, T.C. (2011). Organizational behaviour in education: Leadership and school reform. (10 ${ }^{\text {th }}$ ed.). Boston: Pearson.

Pallant, J. (2011). A step by step guide to data analysis using SPSS: Survival manual. (4 ${ }^{\text {th }}$ ed.). Australia: Allen and Unwin.

Partridge, L. (2007). Managing change: Learning made simple. Amsterdam: Elsevier.

Ramsden, P. (1998). Learning to lead in higher education. London: Rutledge.

Sathye, M. (2004). Leadership in higher education: A qualitative study. Journal of Qualitative Social Research, 15 (3),26 -35.

Shahmandi, E., Silong, A., Ismail, I., Abu Samah, B \& Othman, J. (2011). Competencies, role and effective academic leadership in world class university. International Journal of Business Administration, 2(1), 44 -53.

Starr, K. (2011). Principals and the politics of resistance to change. Educational Management Administration and Leadership, 39(6), 646-660.

Tang, K., MacDermid, J.C., Amick, B.C \& Beaton, D.E. (2011). The 11-item workplace organizational policies and practices questionnaire (OPP-11): Examination of its construct validity, factor structure and predictive 


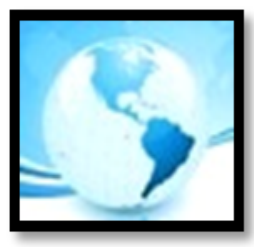

\section{MALAYSIAN ONLINE JOURNAL OF EDUCATIONAL MANAGEMENT (MOJEM)}

validity in injured workers with upper-limb disorder. American Journal of Industrial Medicine, 54(11),834846.

Trochim, W.M., Donnelly, J.P., \& Arora, K. (2016) Research Methods; The essential knowledge base (2nd ed.) Australia: Cengage Learning.

Van der Bijl, J. J., \& Shortridge-Baggett, L. M. (2002). The theory and measurement of the self-efficacy construct. In E. A. Lentz \& L. M. Shortridge-Baggett (Eds.), Self-efficacy in nursing: Research and measurement perspectives. New York: Springer.

Vigoda-Gadot, A. (2007). Leadership style, organizational politics and employees' performance: An empirical examination of two competing models. Personnel Review, 36(5), $661-683$.

Wang, H., Law, K.S., Hackett, R.D., Wang, D \& Chen, Z.X. (2005). Leadership exchange as a mediator of the relationship between transformational leadership and follower's performance and organizational citizenship behaviour, Academy of Management Journal, 18, 420-432.

Yukl, G. (2010). Leadership in organizations, ( ${ }^{\text {th }}$ ed.). Upper Saddle River, New Jersey: Prentice Hall. 